\title{
Dialektisk Atferdsterapi i behandling av suicidal og selvskadende atferd
}

\author{
Av Lars Mehlum
}

\section{SAMMENDRAG}

Dialektisk Atferdsterapi (DBT) ble utviklet for å behandle suicidal og selvskadende atferd hos pasienter med emosjonelt ustabil personlighetsforstyrrelse - en pasientgruppe som mange klinikere opplever som svært utfordrende å hjelpe. I denne artikkelen skal vi se nærmere på hva utfordringene består i, og hvilke strategier DBT bruker som krisetiltak og i langsiktig håndtering av suicidal og selvskadende atferd. Vi skal også gi en kort oversikt over forskningslitteraturen om behandlingsresultater og effekter av DBT når det gjelder å redusere de mange problemene som knytter seg til gjentatt suicidal og selvskadende atferd. Dernest skal vi diskutere hvilke av de mange terapeutiske strategiene i DBT som sannsynligvis har størst betydning som endringsmekanismer i forbindelse med å redusere denne typen atferd.

\section{Dialectical Behaviour Therapy (DBT) was developed to treat} patients with Borderline Personality Disorder (BPD) and suicidal and self-harming behaviour - a group of patients perceived as hard to treat by many clinicians. In this paper we review the most frequent challenges clinicians are facing when treating suicidal BPD patients and what strategies are used in DBT to manage suicidal behaviour in both a short and long-term perspective. We finally provide a brief review of the research literature on the effectiveness of DBT in reducing the many problems associated with repetitive suicidal and self-harming behaviour.

\section{Kronisk suicidalitet og selvskading - utfordrende, men mulig å behandle}

Dialektisk Atferdsterapi (DBT) ble utviklet av den amerikanske psykologen Marsha Linehan med det eksplisitte mål å behandle «kronisk parasuicidale individer med emosjonelt ustabil personlighetsforstyrrelse» (1993). Med «kronisk parasuicidal» mente Linehan gientatt villet egenskadeatferd med eller uten selvmordsintension. Begrepsbruken på dette området har forandret seg giennom årene, og i dag kaller vi denne typen atferd for gientatt eller kronisk selvskading og suicidalitet (Mehlum, 2009). Men selv om begrepene har endret seg en del, forblir den kliniske populasjonen den samme. Vi treffer like mange pasienter med slike problemer på sykehusenes mottaksavdelinger der de kommer til behandling etter at de har skadet seg selv med vilje. Disse pasientene opplever jevnlig suicidale kriser, og de kommer derfor ofte i kontakt med akuttpsykiatriske behandlingstienester. De har ofte hatt mange episoder av kutting eller annen selvskading som gierne er utført som forsøk på å redusere smertefulle og overveldende følelser. Til tross for at vår kunnskap om suicidal og selvskadende atferd har økt i løpet av de siste 30 årene, oppfatter fremdeles helsepersonell denne typen pasientatferd som ekstremt stressende. 
mellom selvskading og suicidal atferd ikke er skarpe, viser klinisk erfaring at selvskading er sterkere knyttet til vansker med å regulere følelser, mens suicidal atferd er sterkere knyttet til depressive tilstander og håpløshet. Selv om selvmordstanker ser ut til å være mer konstant tilstede hos pasienter med ustabil personlighetsforstyrrelse enn hos pasienter med andre psykiske lidelser (Mehlum, Friis, Vaglum, \& Karterud, 1994), er ikke risikoen for suicidal atferd like høy hele tiden. Men når personer med ustabil personlighetsforstyrrelse er i en suicidal krise, har de en sterk tendens til å søke hjelp fra krisetjenester og legevakt (Mellesdal et al., 2015). Mange klinikere er tilbøyelige til å tro at suicidal atferd hos pasienter med ustabil personlighetsforstyrrelse hovedsakelig handler om et rop om hielp eller om kommunikasjon, men uten en sterk intension om å dø. Dette er det ikke støtte for i systematiske studier. Suominen og medarbeidere (2000) undersøkte pasienter innlagt for selvmordsfors $ø$ og sammenliknet dem som hadde en personlighetsforstyrrelse med pasienter

Det som ser ut til å fremme suicidal atferd mer enn noe annet er impulsivitet, som er et personligrisikoen for suicidal atferd ved et bredt spektrum av psykiske lidelser hetstrekk som oker som ikke hadde slik forstyrrelse. Man fant ingen forskiell mellom gruppene verken med hensyn til suicidal intension, håpløshetsfølelse eller dødelighet av selvmordsmetoden som var valgt. Andre studier har imidlertid vist at når personer med cluster-B-personlighetsforstyrrelser (den gruppen av personlighetsforstyrrelser som UPF hører hjemme i) og et mønster av gientatt selvskading faktisk giør selvmordsforsøk, har de en økt tendens til å undervurdere dødeligheten av den selvskadingsmetoden de har valgt og overvurdere sannsynligheten for å få hielp, sammenliknet med personer uten repetitiv selvskadingsatferd (Stanley, Gameroff, Michalsen, \& Mann, 2001).

\section{Hva øker selvmordsrisikoen hos pasienter med ustabil personlighetsforstyrre/se?}

Svikt i regulering av emosioner samt en uttalt sensitivitet overfor miliømessig stress er aspekter ved ustabil personlighetsforstyrrelse som øker risikoen for både suicidal atferd og selvskading (Sher et al., 2016). Men det som ser ut til å fremme suicidal atferd mer enn noe annet er impulsivitet, som er et personlighetstrekk som øker risikoen for suicidal atferd ved et bredt spektrum av psykiske lidelser (Mann, Waternaux, Haas, \& Malone, 1999; Soloff, Lynch, Kelly, Malone, \& Mann, 2000). Som man har sett i en rekke studier har denne impulsiviteten sammenheng med forstyrrelser i serotoninomsetningen i visse hjernestrukturer påvist ved lavere nivåer av serotonin i spinalvæsken (Oquendo \& Mann, 2000). Personer med uttalt impulsivitet er mer sårbare for at negative livshendelser og stress skal forårsake suicidale kriser. I sin biososiale teori peker Linehan på at et samspill mellom en biologisk sårbarhet og negative miliømessige faktorer tidlig i livet kan gi en redusert evne til å regulere følelser, noe som igien øker risikoen for flere typer dysfunksjonell atferd, deriblant suicidal og selvskadende atferd (Linehan, 1993). Selvdestruktiv impulsivitet representerer sannsynligvis den klinisk mest utfordrende delen av de problemene som pasienter med ustabil personlighetsforstyrrelse presenterer, og er også grunnen til at flere aktuelle behandlingsmodeller søker å hielpe pasientene til bedre å kunne kontrollere selvdestruktive impulser og tolerere ubehagelige følelser. Ustabil personlighetsforstyrrelse har en omfattende komorbiditet med andre psykiske lidelser; slik komorbiditet er heller regelen enn unntaket (Skodol et al., 2002). Psykiatrisk komorbiditet ser generelt ut til kraftig å øke alvorlighetsgraden av suicidal atferd (Beautrais et al., 1996), og dette ser ut til å være et enda mer fremtredende mønster når det handler om komorbiditet mellom akse-I- og akse-II-lidelser (Corbitt, Malone, Haas, \& Mann, 1996). Dette er ikke uventet da komorbiditet ofte innebærer at pasientens problemer er mer komplekse og vanskeligere å diagnostisere og behandle, samtidig som pasienten får en alvorligere samlet symptombelastning.

\section{Vansker med å bli værende i behandling}

Individer med ustabil personlighetsforstyrrelse har ofte vansker med å opprettholde gode og nærende relasioner til andre mennesker (Linehan, 1993). Dette viser seg også i samspillet mellom pasient og behandler der pasienten ofte kan føle seg skuffet, avvist eller invalidert. Mange pasienter tar med seg tidlige erfaringer av omsorgssvikt, traumer og avvisning fra familie, venner og helsepersonell de har møtt tidligere. Dermed kan det å bygge et tillitsfullt forhold til pasienten vise seg å være en vanskelig utfordring for behandleren. Likevel vil de fleste klinikere være enige om at det å bygge opp en sterk terapeutisk allianse er et av de aller viktigste selvmordsforebyggende behandlingstiltakene for alle pasienter, men særlig for pasienter med ustabil personlighetsforstyrrelse. Derfor er det naturligvis uheldig at mange av disse pasientene så ofte opplever nettopp brudd i relasjonen til behandlere fordi behandlingen er for kortvarig og blir avsluttet eller overført til en annen enhet eller et annet behandlingsledd. Det er grunn til å anta at hyppige terapeutskifter kan gi dårligere behandlingsresultater og dårligere langtidsprognose (Fonagy \& Bateman, 2006). Det er likevel viktig å merke seg at selvmord hos pasienter med ustabil personlighetsforstyrrelse ofte kommer forholdsvis sent i sykdomsforløpet og ofte etter flere mislykkede behandlingsforsøk (Paris, 2007). 


\section{Hva er god behandling av suicidalitet og selvskading ved ustabil personlighetsforstyrrelse?}

De fleste kliniske retningslinjer, blant dem de britiske NICE-guidelines (NICE, 2011), anbefaler at klinikere i møte med mennesker som skader seg selv med vilie, så tidlig som mulig bør utføre en grundig psykososial vurdering av pasientens psykiske lidelse (inkludert vurderinger av akse-I-/II-komorbiditet og/eller rusmisbruk) samt andre risikofaktorer. Klinikerne bør kartlegge både pasientens ressurser og behov. I vurderingen av risikoen for at pasienten skal gienta suicidal atferd bør klinikeren undersøke selvmordsintensjon og farlighet av den metoden pasienten brukte til å skade seg selv. Videre bør omstendighetene rundt nåværende og tidligere suicidal atferd tas i betraktning. Her bør man kartlegge aktuelle livsvansker, for eksempel mulige mellommenneskelige konflikter eller tap, eksponering for traumatisk stress, mangel på sosial støtte, økonomiske problemer, arbeids- eller skolerelaterte vanskeligheter, somatiske sykdommer og problemer knyttet

Pasienten bor være fullt informert og involvert i å lage mål og ta beslutninger vedrorende sin egen behandling til seksuell orientering. Å utføre en slik systematisk evaluering tar noe tid og er derfor ofte vanskelig å få til i praksis for mange klinikere som treffer pasienter i krise. Kriserelaterte, kortvarige behandlingstiltak legger i utgangs-

punktet ikke til rette for en slik grundig vurdering. En adekvat klinisk vurdering er imidlertid avgiørende for å kunne tilby tilstrekkelig behandling og beskyttelse. Det er også viktig å gienta risikovurderinger siden risikoscenariet raskt kan endre seg hos disse pasientene på grunn av den sterke emosjonelle reaktiviteten og impulsiviteten de ofte har. Mange klinikere unngår å fokusere direkte på suicidalitet i sine terapisesjoner med pasienter med ustabil personlighetsforstyrrelse fordi de er redde for at slik fokusering vil forsterke suicidal atferd. Dette er en lite fruktbar strategi, som vi skal se på senere i artikkelen.

Personer som hyppig skader seg selv med vilje trenger terapeutisk støtte i lengre tid enn bare de første dagene eller ukene etter selvskadingsepisoden. Men skal behandling som strekker seg over tid lykkes, er det nødvendig at klinikeren bygger opp en tillitsfull, støttende og aktiv relasion til pasienten. Behandleren bør også være bevisst på stigma som fortsatt ofte er knyttet til selvskading og suicidalitet, og derfor innta en ikke-dømmende tilnærming. Pasienten bør være fullt informert og involvert i å lage mål og ta beslutninger vedrørende sin egen behandling. Uansett bør viktige mål for behandlingen være å forhindre tilbakefall eller eskalering av suicidal og selvskadende atferd og å stoppe eller redusere annen risikoatferd. Et viktig virkemiddel i å oppnå det, er å utvikle en kriseplan eller sikkerhetsplan. Andre viktige mål vil være å behandle psykiske lidelser som opptrer samtidig, forbedre sosial og yrkesmessig fungering og hjelpe pasienten med å løse problemer som reduserer livskvalitet. Medikamentell behandling har lite for seg som akuttbehandling for selvskading og suicidalitet med mindre den er iverksatt med mål om å behandle en spesifikk psykisk lidelse som for eksempel depresion eller bipolar lidelse. Pasienter bør heller tilbys psykoterapi med en klar struktur og som er basert på en integrert teoretisk tilnærming. De fleste av dagens behandlere har ikke fått god nok opplæring til å kunne tilby integrerte og godt utformede behandlingsprogrammer for pasienter med ustabil personlighetsforstyrrelse (Fairburn \& Cooper, 2011). Dette er en alvorlig utfordring for pasienter, helsepersonell og helsevesen i alle land.

Personer som har repetitiv suicidalitet og selvskading og ustabil personlighetsforstyrrelse er hyppige brukere av sykehustienester (Mellesdal et al., 2015). Men vi har ingen forskningsmessige holdepunkter for at sykehusinnleggelse er effektivt i behandlingen av UPF. De fleste vil være enige om at dersom det er behov for sykehusinnleggelse, bør oppholdet være kort, og fokuset bør ligge på krisehåndtering (NICE, 2oog). Klinikere opplever ofte at spørsmålet om sykehusinnleggelse er et av de mest problematiske når det kommer til å håndtere suicidale kriser hos UPF-pasienter. Flere avveininger må giøres. Det er en reell risiko for at pasienten, hvis hun ikke er beskyttet av et sykehusmiljø, faktisk kan ta sitt eget liv. Men på den andre siden, hvis pasienten blir sykehusinnlagt, kan problemene forverres giennom at det utvikles et negativt samspill mellom pasienten og avdelingspersonalet eller andre pasienter, noe som igien kan lede til økende grad av selvskading eller suicidal atferd. Det finnes alt i alt mange gode grunner til å unngå sykehusinnleggelse hvis mulig. Men hvis behovet for beskyttelse giør sykehusinnleggelse uunngåelig, bør innleggelsen være kort, og man bør tilstrebe å sette en dato for utskrivelse på forhånd (for eksempel «neste morgen» eller «over helgen») og tydelig informere pasienten og de pårørende om hva som er bestemt og hvorfor.

\section{Hvilke strategier benyttes i DBT i behandling av suici- dalitet og selvskading?}

Sette klare behandlingsmål og prioritere mellom ulike mål I dialektisk atferdsterapi gir man behandling av suicidalitet og selvskading topp prioritet blant behandlingsmålene. Dette avviker betydelig fra tilnærmingen som benyttes i de fleste andre behandlingsformer der man som regel satser på å redusere selvmordsrisikoen først og fremst giennom å behandle den psykiske lidelsen som har forårsaket suicidal atferd. Dermed blir hovedstrategien å behandle lidelsen og ikke suicidaliteten. Kliniske studier har imidlertid vist at pasienter med UPF og stadig suicidalitet og selvskading ofte fortsetter med 


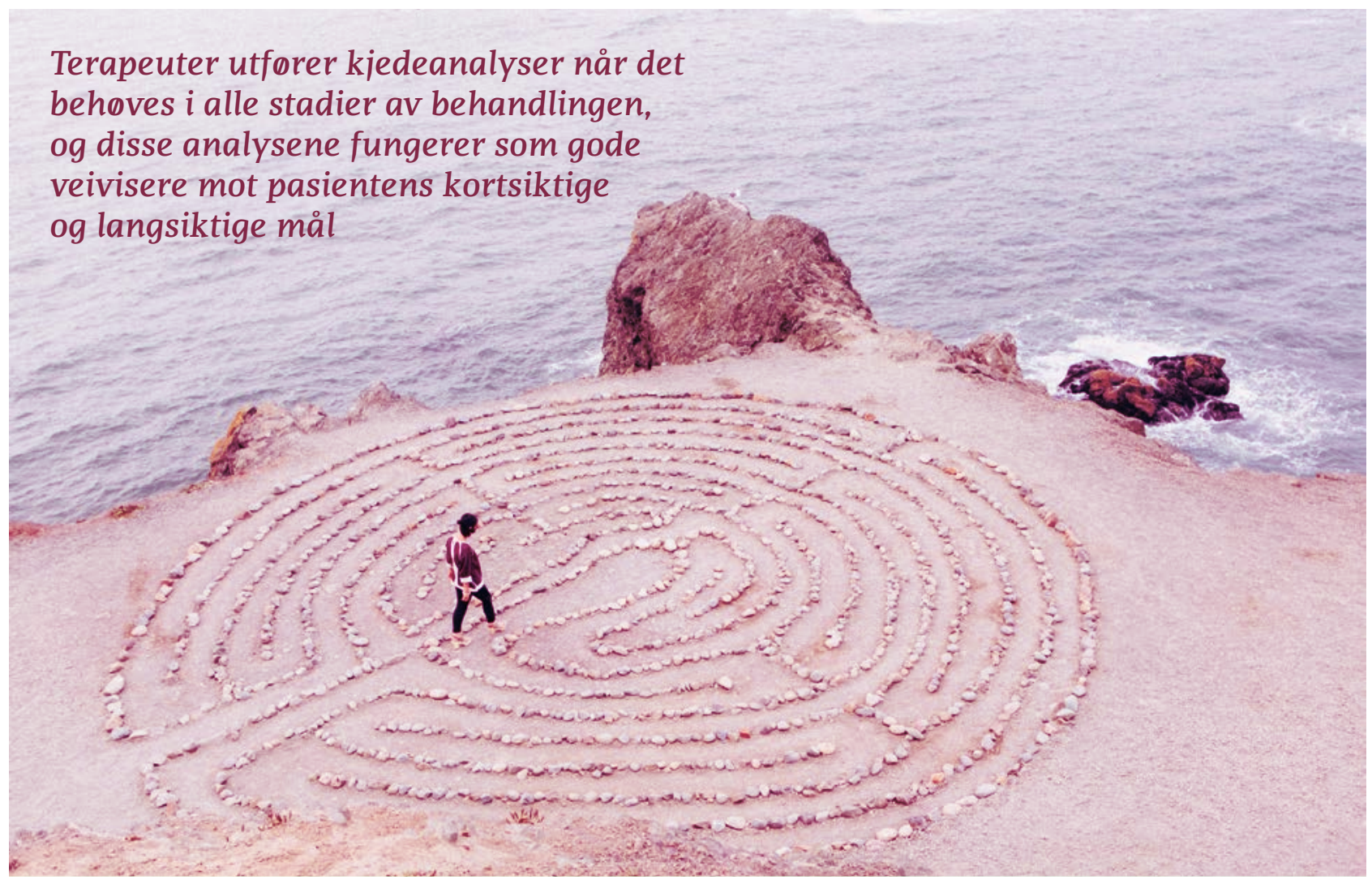

denne atferden over lengre tid selv etter at symptomer på angst og depresion har avtatt (Mehlum et al., 1994). Siden man altså ikke uten videre kan vente at suicidal atferd vil reduseres ved å behandle andre symptomer og problemer, sikter man i DBT på å behandle atferden direkte, og denne praksisen har et godt grunnlag i forskning og klinisk erfaring. Av åpenbare grunner er det viktig at slik behandling gis så tidlig som mulig.

I DBT betraktes suicidal og selvskadende atferd som uttrykk for forsøk på problemløsning. Et sentralt mål i behandlingen blir derfor å erstatte slik livstruende problemløsning med mer funksionelle og sunne mestringsstrategier. Samtidig legger terapeuten stor vekt på å oppnå enighet med pasienten om at dette er et felles mål for pasient og terapeut, og at de samarbeider for å nå dette målet. Pasienten vil på daglig basis monitorere intensiteten av egne selvmordstanker, trangen til å skade seg selv og eventuelle suicidale eller selvskadende handlinger. Denne strategien er vesentlig annerledes enn i de fleste andre behandlingsformer. De fleste pasienter og terapeuter synes suicidal atferd er så ubehagelig å diskutere at de unngår å ta det opp hvis temaet ikke tvinger seg frem. I DBT giør terapeuten det helt fra starten av klart at hun kommer til å ta opp temaet suicidal og selvskadende atferd på rutinebasis, ikke bare i krisesituasjoner. Ved å ta i bruk en slik fremgangsmåte og å snakke om suicidalitet og selvskading på en nøktern, saklig og ikke-dømmende måte, vil terapeuten i stor grad redusere risikoen for utilsiktet å forsterke atferden.

\section{En atferdsorientert tilnærming}

DBT ble utviklet for å behandle kronisk suicidale og selvskadende pasienter med ustabil personlighetsforstyrrelse på en tid da de fleste klinikere betraktet disse pasientene som vanskelige, om ikke umulige, å behandle, og da de fleste klinikere dessuten ofte tydde til sykehusinnleggelse av disse pasientene for å forhindre selvmord - selv om det ikke fantes noe evidensgrunnlag for at det ville redusere selvmordsrisikoen. Da Linehan utviklet sine nye behandlingsmetoder, var hun fullt klar over at selvmordsrisikoen i denne pasientgruppen er høy. Hun nedla derfor mye arbeid i å utvikle nye måter å håndtere denne risikoen på uten at disse tiltakene samtidig skulle stå i veien for å kunne hjelpe pasientene til å få et liv verdt å leve.

DBT ble ikke utviklet primært som en selvmordsforebyggende behandling, men behandlingen har utvilsomt en rekke komponenter som aktivt retter seg mot selvskadende og suicidal atferd. Blant de enkleste, men likevel mest fundamentale komponentene, er det å ganske enkelt betrakte selvmordstanker, selvmords- 
forsøk og selvskading som atferd, og innta en fenomenologisk og ikke-dømmende måte å forholde seg til denne atferden på. Linehan forstod at det å bare unngå å snakke om selvskadende atferd med pasienter, med håpet om at atferden etter hvert vil opphøre på egenhånd, var ineffektivt. Mens terapeuter naturlig nok betrakter suicidal og selvskadende atferd som svært utfordrende problemer, ser pasientene deres ofte på samme atferd som effektive løsninger (Linehan, 1993). I virkeligheten har både terapeuter og pasienter rett. Selvskadende og suicidal atferd fungerer, og den utgiør et alvorlig og ofte livstruende problem. Selvskading er, giennom sin ofte raske og slående effekt på å lindre negative og uutholdelige følelser, en forsterket atferd. I dette tilfellet dreier det seg om negativ forsterkning; det vil si at når ubehaget minker på grunn av atferden, vil atferden opprettholdes. Pasienten vil derfor neppe slutte med denne typen atferd med mindre hun finner alternative måter å effektivt regulere eller tolerere negative følelser på. På samme måte er gientatt suicidal atferd ofte klassisk betingede reaksjoner på stressfaktorer, situasioner eller signaler. Disse faktorene utløser en kjede av følelser, tanker og atferd som i sin tur kan ende i suicidal atferd. I DBT utforsker terapeut og pasient disse hendelseskjedene aktivt og tydelig, samtidig som terapeuten unngår å forsterke atferden.

I DBT giør terapeuten og pasienten sammen en øyeblikk-for-øyeblikk-analyse (kjedeanalyse) av alle de faktorene og hendelsene som for pasienten i den aktuelle situasjonen har bidratt til å utløse, fremme eller opprettholde suicidal eller selvskadende atferd. Dette kan omfatte psykiske, fysiologiske og miliømessige faktorer som fungerte som utløsere, men også faktorer som fungerte som ledd i kjeden, for eksempel følelser eller tanker. Hvordan andre reagerte underveis eller på den selvskadende atferden og hva konsekvensene ble, er også i fokus. Jo flere detaljer som kommer fram, desto nyttigere er denne analysen. Å avgiøre hvorvidt suicidal eller selvskadende atferd hovedsakelig er respondent (knyttet til utløsende faktorer eller hendelser) eller operant (knyttet til konsekvenser av atferden) er av største betydning for å kunne finne de mest hensiktsmessige tiltakene for å redusere atferden. Terapeuter utfører kjedeanalyser når det behøves i alle stadier av behandlingen, og disse analysene fungerer som gode veivisere mot pasientens kortsiktige og langsiktige mål. De fleste pasienter oppfatter kjedeanalysene som nokså ubehagelige. Å fremkalle slikt ubehag er definitivt ikke terapeutens primære hensikt med å bruke denne metoden, men ubehaget kan likevel motvirke eventuelle forsterkende effekter av å diskutere suicidal og selvskadende atferd.

\section{Endring av atferd ved bruk av ferdighetstrening}

For pasienter som har et mønster av gientatt suicidalitet og selvskading, er det viktig å ikke bare fokusere på den enkelte episoden av slik atferd, men også prøve å

avdekke mønstre som går igien fra episode til episode. Når slike mønstre blir tydeligere, er det lettere å velge løsninger og strategier som har virkning på lengre sikt og på tvers av mange situasjoner. Hvis den suicidale atferden hovedsakelig er respondent, bør løsningene sikte mot å unngå hendelser som utløser atferden og å lære ferdigheter i å forebygge, mestre og øke toleransen for slike hendelser. Løsninger kan dreie seg om å gi bedre behandling for psykiske lidelser eller rusmisbruk som øker sårbarheten for at negative livshendelser resulterer i suicidal og selvskadende atferd. Dersom atferden er operant, er det selvfølgelig viktig at terapeuten ikke forsterker denne atferden, men heller forsterker ikke-suicidal, adaptiv atferd samtidig som hun validerer suicidale følelser, og ikke suicidal atferd. En viktig komponent i DBT er å lære bort mestringsferdigheter med mål om å erstatte dysfunksionell atferd med mestrende atferd. Studier har vist at okt bruk av ferdigheter er en sentral virkningsmekanisme i DBT for å redusere suicidal og selvskadende atferd (Neacsiu, Rizvi, \& Linehan, 2010). Et bredt spekter av ferdigheter blir brukt i DBT for å hjelpe pasienter til å endre følelser, tanker og atferd som kan være ledd i den kjeden av faktorer som leder til suicidal eller selvskadende atferd (Linehan, 2015), men det ligger utenfor rammene av denne artikkelen å gi en nærmere beskrivelse av disse.

\section{Krisestrategier}

Terapeuter som behandler suicidale pasienter må regne med at selvmordkriser vil forekomme i løpet av behandlingen, særlig de første ukene eller månedene. Derfor er det viktig å ha en planlagt og systematisk tilnærming til krisehåndtering. I DBT er det lagt vekt

Det er god evidens for at det å senke terskelen for å få hielp i en krise, vil redusere risikoen hos pasienter som får oppfølging etter selvmordsforsøk på at alle terapeuter skal beherske disse metodene - på stående fot. Målet er å redusere risikoen for selvmord og alvorlig skade på kort sikt uten å øke risikoen for slike utfall på lang sikt. Da er det viktig å skille mellom selvmordsforsøk på den ene siden og selvskad-

ing på den andre, selv om linjen mellom disse naturligvis ikke er skarp. Terapeuten lærer pasienten hvordan hun kan monitorere sine egne selvmordstanker og sin egen trang til å skade seg selv, og hva som er forskiellen mellom det ene og det andre. Når kriser oppstår, er det nettopp viktig å velge tiltak avhengig av om krisen medfører økt risiko for selvmord eller om det dreier seg om noe annet. I løpet av terapitimene vil terapeuter hjelpe pasientene sine til å gienkjenne faktorer som ofte utløser kriser og finne fram til ferdigheter og løsninger som kan brukes i det enkelte tilfelle. Dette 
er informasjon som også kan brukes til å utarbeide en sikkerhetsplan som beskriver typiske situasjoner eller følelsesmessige tilstander pasienten bør være oppmerksom på og hva pasienten selv kan giøre for å håndtere situasjonen (f.eks. hvilke ferdigheter som kan brukes). Planen bør også beskrive hvem blant sine venner eller nærmeste pasienten kan søke hjelp fra og hvilke profesjonelle hielpere (med telefonnumre) som pasienten kan kontakte dersom de andre strategiene ikke virker.

De fleste behandlere er lite innstilt på at polikliniske pasienter skal kontakte dem i kriser som oppstår mellom terapitimene, og pasienten deres må derfor henvende seg til legevakt og andre akutt-tjenester i slike situasjoner. Men skal man behandle suicidale pasienter ambulant, vil det være en god idé å legge til rette for at pasientene raskt kan få kontakt ikke bare i kontortiden, men også utenom. Det er god evidens for at det å senke terskelen for å få hjelp i en krise, vil redusere risikoen hos pasienter som får oppfølging etter selvmordsforsøk (Mann et al., 2005). I DBT oppfordres terapeuter til å la pasientene kontakte dem på telefon mellom terapitimene ved behov. Samtidig understrekes betydningen av at terapeuter er konsistente og tydelige overfor sine pasienter og samarbeidspartnere på egne grenser. Mange vil spørre om ikke det å gi økt støtte til pasienten når hun kommuniserer om sine okte selvmordstanker og trang til selvskading vil forsterke atferden. Svaret er at det er en reell risiko for slik forsterking dersom man ikke treffer mottiltak. I DBT er ett av mottiltakene å gi pasienten gode muligheter til å ringe sin terapeut ikke bare i krisesituasjoner, men også i situasjoner der hun trenger hjelp til å bruke ferdigheter for å regulere følelser, mestre mellommenneskelige problemer, be om hielp fra andre eller til å tåle påkjenninger. Det er viktig å merke seg at man i DBT oppfordrer pasienter til å ringe for de har skadet seg selv, slik at terapeuten kan hielpe dem til å bruke krisestrategier eller ferdigheter. Hvis pasienten allerede har skadet seg selv, er det den såkalte «24-timersregelen» som gielder. Den går ut på at pasienten ikke kan ringe terapeuten sin for å få støtte eller hielp til å bruke ferdigheter de påfølgende 24 timene etter å ha skadet seg selv, med unntak av telefonkontakt som er nødvendig for å få hjelp til å behandle skaden.

\section{Sterk terapeutisk allianse}

DBT legger stor vekt på å bygge en sterk terapeutisk allianse til pasienten. Dette er spesielt viktig ut fra hensynet til selvmordsforebygging. Til tider er den sterke terapeutiske alliansen av helt avgiørende betydning for at pasienten klarer å holde seg i live. Skal kronisk suicidale og selvskadende pasienter klare å bearbeide og overvinne de problemene de sliter med, er det ikke til å unngå at de til tider må utholde å bli eksponert for intens emosjonell smerte. Det finnes ingen annen måte for pasienten å bygge et liv som er verdt å leve enn å gå giennom denne smerten. En sterk terapeutisk allianse er en forutsetning for at pasienten skal klare dette. Gitt de mange problemene pasienter med ustabil personlighetsforstyrrelse har med å regulere forholdet til andre mennesker, er det ingen overraskelse at det å skape og opprettholde en sterk terapeutisk allianse kan være vanskelig, både fra terapeutens og pasientens perspektiv. DBT-terapeuter bruker mange strategier for å styrke den terapeutiske alliansen, og en fullstendig giennomgang av disse strategiene faller utenfor denne artikkelens ramme. Det viktigste er imidlertid å skape en samarbeidsrelasion innenfor en validerende og nærende ramme hvor terapeutiske metoder blir anvendt og ny læring kan finne sted (Swales \& Heard, 2007). Terapeuten arbeider for at pasienten tidlig skal observere fremgang i behandlingen, uansett hvor liten denne fremgangen måtte være, siden dette ser ut til å være blant faktorene som styrker en terapeutisk allianse. Det å sette overambisiøse mål tidlig i behandlingen, ser derimot ut til å virke i motsatt retning. Terapeuter er også opptatt av så mye som mulig å engasjere og aktivt motivere pasienter i behandlingen giennom å bruke både validerings- og forpliktelsesstrategier for å forhindre at pasienten skal droppe ut.

\section{Behandling av ungdommer - en familietilnærming}

Mange studier har vist at både suicidal og selvskadende atferd hos ungdom kan være nært knyttet til problemer i familien (D. Brent, 2010). I noen tilfeller er disse problemene årsaksfaktorer, mens i andre tilfeller kan familier som ikke har forårsaket problemene, likevel forsterke dem. I alle tilfeller spiller familier en viktig rolle når det gielder å finne løsninger og å hielpe ungdommer til å giøre fremgang i behandlingen. Forskning viser at skal behandling med mål om å redusere suicidal atferd hos ungdommer ha effekt, må den omfatte en eller annen form for familiestøtte, og den må forholde seg til familiers fungeringsproblemer (D. A. Brent et al., 2013). DBT er blitt tilpasset for ungdommer og deres familier giennom blant annet å inkludere en rekke familiestrategier (Miller, Rathus, \& Linehan, 2007). Denne formen for DBT omfatter alle komponentene man finner i standard DBT, men det er foretatt tilpasninger som giør det mulig å arbeide spesifikt med typiske dilemmaer som man ofte finner hos ungdommer med følelsesmessige reguleringsproblemer og suicidal og selvskadende atferd. En tilpasning er også at foresatte blir trukket aktivt inn i behandlingen giennom ferdighetstrening og familieterapi. Ferdighetstreningen skjer i grupper der flere familier deltar sammen og der foreldre deltar på samme vilkår som ungdommene, noe som betyr at de må øve på ferdighetene som blir lært bort i like høy grad som alle andre. Dette er av spesiell verdi for foreldre, siden det å hielpe sin egen ungdom til å bruke ferdigheter i dagliglivet utenfor terapitimene blir lettere når en selv har inngående kunnskap om hvilke ferdigheter som behøves og utfordringene ved å ta dem effektivt i bruk i en krisesituasjon. 


\section{Effekten av DBT på suicidal og selvskadende atferd - Hva sier forskningen?}

At DBT er en effektiv behandlingsmetode er godt dokumentert giennom en lang rekke studier og i systematiske litteraturgiennomganger (Kliem, Kroger, \& Kosfelder, 2010; Stoffers et al., 2012). I denne artikkelen skal vi gi en kort oversikt over hva forskningen sier om effektene av DBT på suicidal og selvskadende atferd og på symptomer og problemer som er tett knyttet til slik atferd. Vi skal også se nærmere på hvilken effekt DBT har på bruk av akutt-tienester som følge av selvmordskriser. Et problem i all intervensjonsforskning som fokuserer på suicidal atferd er at selv hos svært risikoutsatte grupper som pasienter med ustabil personlighetsforstyrrelse og mange selvmordsforsøk i sykehistorien, forekommer nye selvmordsforsøk relativt sielden. Siden behandlingsstudier typisk har et begrenset tidsperspektiv, kan det derfor bli vanskelig med noen grad av presisjon å måle forandring over tid og undersøke eventuelle ulikheter i slike utfall mellom grupper som har mottatt ulike typer av behandling. Noen studier har derfor valgt å slå sammen suicidal atferd og selvskading til én kategori for å oppnå bedre statistisk teststyrke.

\section{Suicidal atferd}

Oppfølgingsstudier har konsekvent vist at personer som har giort et selvmordsforsøk har en sterkt økt risiko for gientatte selvmordsforsøk og selvmord i løpet av det påfølgende første året (Haw, Bergen, Casey, \& Hawton, 2007; K. Suominen et al., 2004). Å gi effektiv oppfølging i etterkant av selvmordsforsøk er derfor et høyt prioritert selvmordsforebyggende tiltak (Mann et al., 2005). Hittil er det bare et fåtall behandlingstyper som har vist seg effektive for å redusere suicidal atferd hos pasienter som har giort selvmordsforsøk. Blant disse behandlingene er det uten tvil DBT som har det sterkeste empiriske grunnlaget for en slik effekt på tvers av diagnostiske grupper og behandlingskontekster (Stoffers et al., 2012). I den forste av de forholdsvis mange effektstudiene som har vært utført på DBT (Linehan, Armstrong, Suarez, Allmon, \& Heard, 1991), skilte man ikke mellom selvmordsforsøk og selvskading, men studerte i stedet behandlingens effekt på «parasuicid» som en samlekategori, som nevnt tidligere. Pasienter med ustabil personlighetsforstyrrelse som fikk ett års standard DBT rapporterte betydelig færre parasuicidale episoder enn pasienter som fikk ett år med vanlig behandling. Den største delen av denne effekten inntraff allerede i lopet av de første fire månedene av behandlingen, og effekten vedvarte de første seks månedene etter behandlingsslutt (Linehan, Heard, \& Armstrong, 1993). Denne første studien er senere replikert av flere uavhengige forskergrupper (Koons et al., 2001; Turner, 2000), mens andre har funnet den samme fordelaktige responsen på DBT med hensyn til suicidal atferd, men uten å finne statistisk signifikante forskjeller mellom DBT og

behandlinger som man har sammenliknet med (Carter, Willcox, Lewin, Conrad, \& Bendit, 2010; Clarkin, Levy, Lenzenweger, \& Kernberg, 2007; Verheul et al., 2003). I en senere randomisert kontrollert studie sammenliknet Linehan ett års standard DBT med ett års nonDBT-behandling gitt av eksperter (Linehan et al., 2006). Pasienter som fikk DBT rapporterte bare halvparten så mange selvmordsforsøk i løpet av behandlingsperioden som pasientene i sammenligningsgruppen. Fordi begge behandlingene ble utført av eksperter, kunne ikke den gunstigere effekten av DBT tilskrives terapeutenes generelle kompetansenivå og erfaring eller terapeutenes tro på sin egen behandling. Den mest plausible forklaringen på den større effekten av DBT er de mange strategiene i DBT som nettopp retter seg mot suicidal atferd og som vi har beskrevet ovenfor. Slike strategier har hittil i liten grad blitt tatt i bruk i andre behandlingsmodeller, selv når behandlingen er blitt utført med ellers høy kompetanse. Ferdighetstrening er et eksempel på strategier som står sentralt i DBT. I en analyse av data fra tre randomiserte kontrollerte studier, viste Linehan-gruppen at bruk av ferdigheter var en signifikant mediator for reduksjon i forekomsten av selvmordsforsøk over tid. Dette tyder på at økt ferdighetsbruk er en viktig endringsmekanisme for å redusere suicidal atferd (Neacsiu et al., 2010). I en nyere studie gikk Linehan et skritt videre i å studere den relative betydningen av ferdighets-

Både etter ett års behandling og ved ett års oppfolgning etter behandlingsslutt fant man like gode behandlingsresultater $i$ alle tre grupper når det gialdt hyppighet og alvorlighetsgrad av selvmordsforsøk trening i behandling av suicidale pasienter med ustabil personlighetsforstyrrelse. Hun sammenliknet pasienter som fikk ett års DBT ferdighetstrening som frittstående behandling med pasienter som fikk DBT uten ferdighetstrening (bare individualterapi) og pasienter som fikk standard DBT der både ferdighetsopplæring og individualterapi inngår (Linehan et al., 2015).

Både etter ett års behandling og ved ett års oppfølgning etter behandlingsslutt fant man like gode behandlingsresultater i alle tre grupper når det gialdt hyppighet og alvorlighetsgrad av selvmordsforsøk. Man fant også like sterk reduksjon i nivået av selvmordstanker. Dette funnet står tilsynelatende i kontrast til Linehans tidligere funn at ferdighetstrening har en viktig rolle i å redusere selvmordsforsøk over tid, og kan tyde på at reduksionen av suicidal atferd giennom bruk av DBT er avhengig av mer enn ferdighetstrening, slik vi også har beskrevet ovenfor. 
I den største randomiserte kontrollerte studien av psykoterapi for suicidale pasienter med ustabil personlighetsforstyrrelse som er utført til dags dato, sammenliknet McMain og medarbeidere ett år med standard DBT med «generell psykiatrisk behandling», og fant at pasienter i begge grupper fikk like sterk bedring med hensyn til hyppighet og alvorlighetsgrad av både selvmordsforsøk og selvskading (McMain et al., 2009). Disse effektene holdt seg også to år etter behandling (McMain, Guimond, Streiner, Cardish, \& Links, 2012). Det er viktig å være klar over at det som i denne studien ble kalt «generell psykiatrisk behandling» $\mathrm{i}$ realiteten var en manualbasert behandling av høy standard utviklet på grunnlag av faglige retningslinjer fra den amerikanske psykiaterforeningen (American Psychiatric Association Practice, 2001). Behandlingen besto av psykodynamisk psykoterapi, medikamentell behandling og ellers tett oppfølging. Denne studien kan tyde på at man ikke kan forvente å finne store forskjeller når det gielder reduksjon av suicidal atferd hos pasienter med ustabil personlighetsforstyrrelse når man sammenlikner behandlinger som holder meget høy standard.

DBT har blitt tilpasset for en rekke undergrupper av pasienter og behandlingskontekster. Den viktigste av disse er nok DBT-tilpasningen for ungdommer som vi har nevnt tidligere. Både suicidal og selvskadende atferd forekommer hyppig blant ungdom (Madge et al., 2008), og dette giør naturligvis DBT til en potensielt meget relevant behandling å tilby pasienter i denne aldersgruppen. Ungdomstilpasningen er kortere (16-20 uker) enn standard DBT (ett år) og trekker ungdommenes familier inn i behandlingen. I en norsk studie ble denne DBT-varianten sammenliknet med vanlig BUP-behandling for ungdommer med gientatt suicidalitet og selvskading og trekk fra ustabil personlighetsforstyrrelse, og man fant at DBT førte til en signifikant sterkere reduksion i villet egenskade, selvmordstanker og depresjonssymptomer enn vanlig BUP-behandling (Mehlum et al., 2014). Behandlingseffektene holdt seg også ett år etter behandlingsslutt (Mehlum et al., 2016).

\section{Selvskading}

Flere studier har undersøkt effekten av DBT når det gielder å redusere forekomsten av selvmordsforsøk og selvskading hver for seg. Dette er viktig siden behandlingen av disse to atferdene bør være forskjellig, som tidligere nevnt, og man derfor ikke uten videre kan forvente at disse to utfallene vil reagere likt på behandlingen. Det er imidlertid utfordrende å studere selvskading som utfall. Mange pasienter er unnvikende i samtale med behandlere eller forskere om selvskadingen, og det er derfor lett å undervurdere omfanget. Det finnes også en mengde ulike typer av selvskading som klinikere og forskere må spørre nokså detaljert etter dersom de skal få et inntrykk av hvor hyppig de forekommer. Selvskadingsepisoder kan forekomme

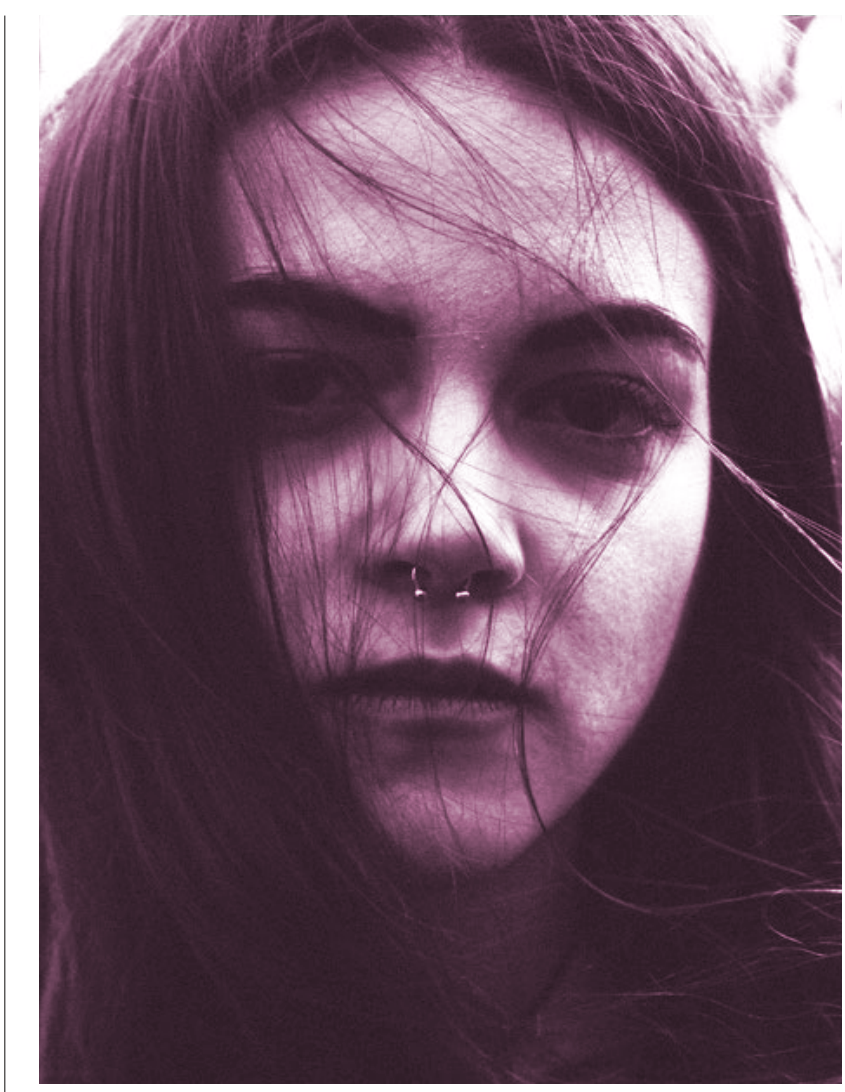

svært hyppig, opptil dusinvis av ganger per dag, og det kan være vanskelig å få en god oversikt over antallet og over eventuelle endringer over tid. Det er også vanskelig å sammenlikne data som er så lite normalfordelte som antall selvskadingsepisoder når man skal beregne forskieller mellom pasientgrupper og endring over tid.

En av studiene som har rapportert separat på selvmordsforsøk og selvskading er den nederlandske studien av standard DBT utført av Verheul og medarbeidere (2003). Man fant ingen forskjell i forekomst av selvmordsforsøk mellom pasienter som fikk ett års standard DBT og de som fikk vanlig behandling. Derimot fant man en signifikant sterkere reduksjon i selvskading blant pasienter som hadde fått DBT, og denne effekten var holdt seg ved oppfølging 6 måneder etter behandlingsslutt (van den Bosch, Koeter, Stijnen, Verheul, \& van den Brink, 2005). I en studie utført av Pistorello og medarbeidere fikk suicidale studenter med UPF-trekk 7-12 måneder med enten DBT eller optimalisert vanlig behandling, og man fant at pasienter i DBT-gruppa rapporterte et betydelig lavere antall selvskadingsepisoder, lavere nivå av selvmordstanker og en sterkere reduksion av UPF-kriterier enn de som fikk vanlig behandling (Pistorello, Fruzzetti, MacLane, Gallop, \& Iversson, 2012). I Linehans komponentstudie fra 2015, nevnt ovenfor, opplevde pasienter som hadde 
fått DBT med ferdighetstrening betydelig sterkere reduksion av selvskadingsepisoder enn pasienter som hadde fått DBT uten ferdighetstrening (Linehan et al., 2015). Dette kan tyde på at ferdighetstrening er en nødvendig komponent i behandlingen dersom man onsker å oppnå reduksjon av selvskading, mens ferdighetstrening muligens ikke er nødvendig for å få reduksjon i suicidal atferd, slik vi har sett tidligere.

\section{Bruk av krisetjenester og sykehusinnleggelser}

I Linehans forste effektstudie hadde pasienter som fikk DBT signifikant færre psykiatriske innleggelsesdager både i løpet av behandlingsåret og i observasjonsperioden etter behandlingsslutt (Linehan et al., 1993). I Linehans studie fra 2006 som sammenliknet DBT med terapi utført av eksperter, fant man mer enn $50 \%$ reduksion i antall legevaktbesøk og mer enn $70 \%$ reduksion i antall sykehusinnleggelser som følge av suicidalitet blant pasienter som fikk DBT (Linehan et al., 2006) i forhold til sammenlikningsgruppen. Disse resultatene holdt seg giennom oppfølgingsperioden på ett år, og funnene er også giort i studier utfort av uavhengige grupper (Koons et al., 2001; Turner, 2000). Disse effektene er viktige av flere grunner. For det første er det et svakt empirisk grunnlag for effekten av sykehusinnleggelse av suicidale pasienter med ustabil personlighetsforstyrrelse (NICE, 2009). De høye kostnadene ved psykiatrisk innleggelse er derfor et godt argument for å satse på behandling som gir god effekt samtidig som den reduserer behovet for innleggelse. For det andre er sykehusinnleggelse, frivillig eller med tvang, et meget forstyrrende inngrep i de fleste pasienters hverdagsliv, og innleggelse medfører også ofte avbrudd i pågående poliklinisk behandling. For det tredje kan sykehusinnleggelse bidra til å forsterke og opprettholde suicidal og selvskadende atferd. Hver ny episode av slik atferd vil nærmest uunngåelig bli forsterket av den økte omsorgen og oppfølgingen fra helsepersonell som en sykehusinnleggelse medfører.

\section{Andre utfall}

Et bredt spekter av symptomer, problemer, emosioner og atferd er assosiert med økt risiko for suicidal og selvskadende atferd hos personer med ustabil personlighetsforstyrrelse. I denne sammenheng vil vi bare omtale noen av de viktigste. En stor andel av pasienter med UPF har også depresion, og suicidal atferd er ofte sterkt knyttet til depressive tilstander også hos disse pasientene. En rekke kliniske studier har vist at DBT gir en sterkere reduksion av depressive symptomer enn den behandlingen som sammenligningsgrupper har fått i disse studiene (Koons et al., 2001; Mehlum et al., 2014; Pistorello et al., 2012; Turner, 2000). Man har tilsvarende funnet en sterkere reduksjon i nivået av håpløshetsfølelse blant pasienter som har mottatt DBT i flere studier (Koons et al., 2001; Mehlum et al., 2014). Flere studier har også vist at antall oppfylte kriterier for UPF-diagnosen eller borderlinesymptomer har blitt betydelig mer redusert hos pasienter som har fått DBT enn hos dem som fikk annen behandling (Mehlum et al., 2014; Pistorello et al., 2012), og disse effektene har man interessant nok hittil bare funnet i studier av unge pasientgrupper. Atferder eller problemer typisk for personer med UPF, som for eksempel sinne (Koons et al., 2001; Linehan et al., 1991; Turner, 2000), impulsivitet og følelsesmessig reguleringssvikt (Turner, 2000), har man også funnet at blir betydelig mer redusert hos UPF-pasienter som mottar DBT.

\section{Konklusjoner}

Som vist i denne artikkelen har dialektisk atferdsterapi en rekke tilnærminger og strategier som tar sikte på å forebygge suicidal og selvskadende atferd, og en rekke studier har vist at behandlingen har effekt på slik atferd. I tillegg har forskning vist at DBT reduserer antall legevaktbesøk og innleggelsesdager på sykehus utløst av suicidal atferd og en rekke symptomer og problemer knyttet til suicidalitet. Dette er viktig informasjon som bør føre til at DBT blir tatt mer systematisk i bruk i tjenesteapparatet enn i dag, både i Norge og andre land. Vi mangler imidlertid sikre kunnskaper om hvilke DBT-strategier som er sentrale for å forklare disse behandlingseffektene og som derfor er uunnværlige i behandlingen. Behandlingsstrategier som det å anvende en atferdsmessig tilnærming til suicidal og selvskadende atferd for dermed å kunne identifisere faktorer som forårsaker eller opprettholder disse typene av atferd er trolig ganske sentrale. Å fokusere direkte og spesifikt på suicidal og selvskadende atferd i behandlingen og å giøre dette til en topp prioritet er trolig også svært viktig. De mange spesifikke strategiene DBT anvender for å forebygge selvmordskriser og for å håndtere slike kriser når de tross alt forekommer kan antakeligvis også forklare de gode behandlingsresultatene. Særlig det å lære pasienter ferdigheter i å regulere følelser, utholde stress og løse mellommenneskelige problemer og samtidig hjelpe pasientene til aktivt å bruke ferdighetene i kriser og andre utfordrende situasioner i dagliglivet, er til stor hielp for mange. Endelig kan den sterke vektleggingen av å bygge en god terapeutisk relasjon til pasienten trolig bidra til å forklare hvordan det er mulig å få pasienter til å fortsette i behandlingen og holde seg i live til tross for sine store problemer med å regulere følelser og tolerere stress.

\section{LITTERATURLISTE}

American Psychiatric Association Practice, Guidelines. (2001). Practice guideline for the treatment of patients with borderline personality disorder. American Psychiatric Association. Am I Psychiatry, 158(10 Suppl), 1-52.

Beautrais, A. L., Joyce, P. R., Mulder, R. T., Fergusson, D. M., Deavoll, B. I., \& Nightingale, S. K. (1996). Prevalence and comorbidity of mental disorders in persons making serious suicide attempts: a case-control study. Am I Psychiatry, 153(8), 1009-1014. doi: 10.1176/ajp.153.8.1009 
Black, D. W., Blum, N., Pfohl, B., \& Hale, N. (2004). Suicidal behavior in borderline personality disorder: prevalence, risk factors, prediction, and prevention. J Pers Disord, 18(3), 226-239. doi: 10.1521/pedi.18.3.226.35445

Brent, D. (2010). What family studies teach us about suicidal behavior: implications for research, treatment, and prevention. Eur Psychiatry, 25(5), 260-263. doi: 10.1016/i.eurpsy.2009.12.009

Brent, D. A., McMakin, D. L., Kennard, B. D., Goldstein, T. R., Mayes, T. L. \& Douaihy, A. B. (2013). Protecting adolescents from self-harm: a critical review of intervention studies. I Am Acad Child Adolesc Psychiatry, 52(12), 126o-1271. doi: 10.1016/i.jaac.2013.09.009

Carter, G. L., Willcox, C. H., Lewin, T. I., Conrad, A. M., \& Bendit, N. (2010). Hunter DBT project: randomized controlled trial of dialectical behaviour therapy in women with borderline personality disorder. Aust.N.Z.I.Psychiatry, 44(2), 162-173

Clarkin, I. F., Levy, K. N., Lenzenweger, M. F., \& Kernberg, O. F. (2007). Evaluating three treatments for borderline personality disorder: a multiwave study. American Journal of Psychiatry, 164(6), 922-928.

Corbitt, E. M., Malone, K. M., Haas, G. L., \& Mann, I. I. (1996). Suicidal behav ior in patients with major depression and comorbid personality disorders. I Affect Disord, 39(1), 61-72.

Fairburn, C. G., \& Cooper, Z. (2011). Therapist competence, therapy quality, and therapist training. Behav Res Ther, 49(6-7), 373-378. doi: 10.1016/j. brat.2011.03.005

Fonagy, P., \& Bateman, A. (2006). Progress in the treatment of borderline personality disorder. Br I Psychiatry, 188, 1-3. doi: 10.1192/bip.bp.105.012088

Haw, C., Bergen, H., Casey, D., \& Hawton, K. (2007). Repetition of deliberate self-harm: a study of the characteristics and subsequent deaths in patients presenting to a general hospital according to extent of repetition. Suicide Life Threat Behav, 37(4), 379-396. doi: 10.1521/suli.2007.37.4.379

Kliem, S., Kroger, C., \& Kosfelder, I. (2010). Dialectical behavior therapy for borderline personality disorder: a meta-analysis using mixed-effects modeling. I Consult Clin Psychol, 78(6), 936-951. doi: 10.1037/aoo21015

Koons, C. R., Robins, C. I., Tweed, I. L., Lynch, T. R., Gonzalez, A. M., Morse I. Q., ... Bastian, L. A. (2001). Efficacy of dialectical behavior therapy in women veterans with borderline personality disorder. Behavior Therapy, 32, 371-390.

Linehan, M. M. (2015). DBT Skills Training Manual, Second Edition (2 ed.). New York: Guilford Publications.

Linehan, M. M., Armstrong, H. E., Suarez, A., Allmon, D., \& Heard, H. L. (1991). Cognitive-behavioral treatment of chronically parasuicidal borderline patients. Arch.Gen.Psychiatry, 48(12), 1060-1064.

Linehan, M. M., Heard, H. L., \& Armstrong, H. E. (1993). Naturalistic follow-up of a behavioral treatment for chronically parasuicidal borderline patients. Arch Gen Psychiatry, 50(12), 971-974.

Linehan, M. M., Korslund, K. E., Harned, M. S., Gallop, R. I., Lungu, A., Neac siu, A. D., . . Murray-Gregory, A. M. (2015). Dialectical behavior therapy for high suicide risk in individuals with borderline personality disorder: a randomized clinical trial and component analysis. JAMA Psychiatry, 72(5), 475-482. doi: 10.1001/iamapsychiatry.2014.3039

Linehan, Marsha M. (1993). Cognitive-behavioral treatment of borderline personality disorder. New York: Guilford Press.

Linehan, Marsha M., Comtois, Katherine Anne, Murray, Angela M., Brown, Milton Z., Gallop, Robert I.. Heard, Heidi L., ... Lindenboim, Noam. (2006). Two-Year Randomized Controlled Trial and Follow-up of Dialectical Behavior Therapy vs Therapy by Experts for Suicidal Behaviors and Borderline Personality Disorder. Arch Gen Psychiatry, 63(7), 757-766.

Madge, N., Hewitt, A., Hawton, K., de Wilde, E. I., Corcoran, P., Fekete, S., . .. Ystgaard, M. (2008). Deliberate self-harm within an international community sample of young people: comparative findings from the Child and Adolescent Self-harm in Europe (CASE) Study. I Child Psychol Psychiatry, 49(6), 667-677. doi: 10.1111/j.1469-7610.2008.01879.x
Mann, I. I., Apter, A., Bertolote, I., Beautrais, A., Currier, D., Haas, A., . . Hendin, H. (2005). Suicide prevention strategies: a systematic review. IAMA, 294(16), 2064-2074. doi: 10.1001/jama.294.16.2064

Mann, I. I., Waternaux, C., Haas, G. L., \& Malone, K. M. (1999). Toward a clinical model of suicidal behavior in psychiatric patients. Am I Psychiatry, 156(2), 181-189. doi: 10.1176/ajp.156.2.181

McMain, S. F., Guimond, T., Streiner, D. L., Cardish, R. I., \& Links, P. S. (2012). Dialectical Behavior Therapy Compared With General Psychiatric Management for Borderline Personality Disorder: Clinical Outcomes and Functioning Over a 2-Year Follo-Up Am I Psychiatry, 169, 11

McMain, S. F., Links, P. S., Gnam, W. H., Guimond, T., Cardish, R. I., Korman, L., \& Streiner, D. L. (2009). A randomized trial of dialectical behavior therapy versus general psychiatric management for borderline personality disorder. Am.I.Psychiatry, 166(12), 1365-1374.

Mehlum, L. (2009). Clinical challenges in the assessment and management of suicidal behaviour in patients with bordeline personality disorder. Epidemiol Psichiatr Soc, 18(3), 184-19o.

Mehlum, L., Friis, S., Vaglum, P., \& Karterud, S. (1994). The longitudinal pattern of suicidal behaviour in borderline personality disorder: a prospective follow-up study. Acta Psychiatr Scand, 90(2), 124-130.

Mehlum, L., Ramberg, M., Tormoen, A. I., Haga, E., Diep, L. M., Stanley, B. H., ... Groholt, B. (2016). Dialectical Behavior Therapy Compared With Enhanced Usual Care for Adolescents With Repeated Suicidal and Self-Harming Behavior: Outcomes Over a One-Year Follow-Up. I Am Acad Child Adolesc Psychiatry, 55(4), 295-300. doi: 10.1016/i.jaac.2016.01.005

Mehlum, L., Tormoen, A. I., Ramberg, M., Haga, E., Diep, L. M., Laberg, S., . . . Groholt, B. (2014). Dialectical Behavior Therapy for Adolescents With Repeated Suicidal and Self-harming Behavior: A Randomized Trial. I Am Acad Child Adolesc Psychiatry, 53(10), 1082-1091. doi: 10.1016/i.jaac.2014.07.003

Mellesdal, L., Gjestad, R., Johnsen, E., Jorgensen, H. A., Oedegaard, K. I. Kroken, R. A., \& Mehlum, L. (2015). Borderline Personality Disorder and Posttraumatic Stress Disorder at Psychiatric Discharge Predict General Hospital Admission for Self-Harm. I Trauma Stress, 28(6), 556-562. doi: $10.1002 /$ its. 22053

Miller, A. L., Rathus, I. H., \& Linehan, M. M. (2007). Dialectical Behavior Therapy with Suicidal Adolescents. New York: Guilford.

Neacsiu, A. D., Rizvi, S. L., \& Linehan, M. M. (2010). Dialectical behavior therapy skills use as a mediator and outcome of treatment for borderline personality disorder. Behav.Res.Ther., 48(9), 832-839.

NICE. (2009). Borderline Personality Disorder: Recognition and Management. Clinical Guideline. 2017, from nice.org.uk/guidance/ca78

NICE. (2011). Self-harm in over 8s: long-term management NICE Guidance. London: National Institute for Health and Care Excellence.

Oldham, I. M. (2006). Borderline personality disorder and suicidality. Am Psychiatry, 163(1), 20-26. doi: 10.1176/appi.aip.163.1.20

Oquendo, M. A., \& Mann, I. I. (2000). The biology of impulsivity and suicidality. Psychiatr.Clin North Am., 23(1), 11-25.

Paris, I. (2007). Half in love with death. Managing the Chronically Suicidal Patient. New York: Routledge.

Pistorello, I., Fruzzetti, A.E., MacLane, C., Gallop, R. I., \& Iversson, K.M. (2012). Dialectical Behavior Therapy (DBT) Applied to College Students: A Randomized Clinical Trial. I Consult Clin Psychol, 8o(6), 8.

Sher, L., Fisher, A. M., Kelliher, C. H., Penner, I. D., Goodman, M., Koenigsberg, H. W., . . . Hazlett, E. A. (2016). Clinical features and psychiatric comorbidities of borderline personality disorder patients with versus withou a history of suicide attempt. Psychiatry Res, 246, 261-266. doi: 10.1016/i. psychres.2016.10.003

Skodol, A. E., Gunderson, I. G., Pfohl, B., Widiger, T. A., Livesley, W. I., \& Siever, L. I. (2002). The borderline diagnosis I: psychopathology, comorbidity, and personality structure. Biol Psychiatry, 51(12), 936-950. 
Soloff, P. H., Lynch, K. G., Kelly, T. M., Malone, K. M., \& Mann, I. I. (2000). Characteristics of suicide attempts of patients with major depressive episode and borderline personality disorder: a comparative study. Am I Psychiatry, 157, 601-608.

Stanley, B., Gameroff, M. J., Michalsen, V., \& Mann, I. I. (2001). Are suicide attempters who self-mutilate a unique population? American Journal of Psychiatry, 158(3), 427-432. doi: DOI 10.1176/appi.ajp.158.3.427

Stoffers, I. M., Vollm, B. A., Rucker, G., Timmer, A., Huband, N., \& Lieb, K. (2012). Psychological therapies for people with borderline personality disorder. Cochrane Database Syst Rev(8), CDoo5652. doi: 10.1002/14651858. CDoo5652.pub2

Stoffers, I. M., Völlm, B. A., Rücker, G., TImmer, A. , Huband, N. , \& Lieb, K. (2010). Pharmacological interventions for borderline personality disorder (Review) Cochrane Database of Systematic Reviews (Vol. 2010). London: Cochrane Library.

Suominen, K. H., Isometsa, E. T., Henriksson, M. M., Ostamo, A. I., \& Lonnqvist, I. K. (2000). Suicide attempts and personality disorder. Acta Psychiatr Scand, 102(2), 118-125.

Suominen, K., Isometsa, E., Suokas, I., Haukka, J., Achte, K., \& Lonnqvist, I. (2004). Completed suicide after a suicide attempt: a 37-year follow-up study. Am I Psychiatry, 161(3), 562-563. doi: 10.1176/appi.ajp.161.3.562

Swales, M.A., \& Heard, H. L. (2007). The therapy relationship in dialectical behaviour therapy. In P. Gilbert \& R. Leahy (Eds.), The therapeutic relationship in the cognitive behavioral psychotherapies. (pp. 185-204). New York: Routledge.

Turner, R.M. (2000). Naturalistic Evaluation of Dialectical Behavior Therapy - Oriented Treatment for Borderline Personality Disorder. Cognitive and Behavioral Practice, 7, 7.

van den Bosch, L. M., Koeter, M. W., Stijnen, T., Verheul, R., \& van den Brink, W. (2005). Sustained Efficacy of Dialectical Behaviour Therapy for Borderline Personality Disorder. Behavior Research and Therapy, 43, 10.

Verheul, R., Van Den Bosch, L. M., Koeter, M. W., De Ridder, M. A., Stiinen, T., \& Van Den, Brink W. (2003). Dialectical behaviour therapy for women with borderline personality disorder: 12 -month, randomised clinical trial in The Netherlands. Br.J Psychiatry, 182, 135-140.

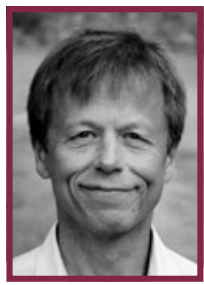

LARS MEHLUM er professor dr. med. og leder av NSSF, Institutt for klinisk medisin, Universitetet i Oslo. 